Voix et Images

volxetimages

\title{
Jacques Allard, boursier Killam
}

\section{La Direction}

Volume 11, numéro 1, automne 1985

\section{Naïm Kattan}

URI : https://id.erudit.org/iderudit/200532ar

DOI : https://doi.org/10.7202/200532ar

Aller au sommaire du numéro

Éditeur(s)

Université du Québec à Montréal

ISSN

0318-9201 (imprimé)

1705-933X (numérique)

Découvrir la revue

Citer ce document

La Direction (1985). Jacques Allard, boursier Killam. Voix et Images, 11(1), 7-7. https://doi.org/10.7202/200532ar d'utilisation que vous pouvez consulter en ligne.

https://apropos.erudit.org/fr/usagers/politique-dutilisation/ 


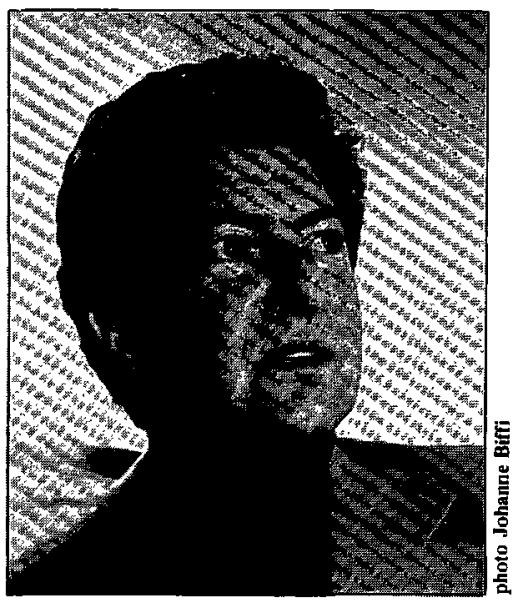

\section{JACQUES ALLARD, BOURSIER KILLAM}

La direction et le comité de rédaction de Voix et Images tiennent à féliciter Jacques Allard pour l'obtention récente de la bourse Killam en littérature québécoise. Collaborateur de la première heure (voilà dix-huit ans aux Cahiers Sainte-Marie), il a dirigé notre revue de 1975 à 1981 , siégeant par la suite à notre comité.

Sa recherche des deux prochaines années portera sur Les discours québécois: thèmes et formes des discours politiques, religieux et amoureux dans la prose narrative des cent dernières années.

La Direction 